\title{
The Concept of Sovereignty in Relation to the State and Power
}

\author{
Emirjola Yzeiraj \\ Faculty of Philology, Albania
}

\begin{abstract}
In this paper we will analyze two main questions: Does sovereignty exist? Where does the force of sovereignty lie? If we discuss absolute sovereignty as self-government with a relatively high independence and a relatively high power, the question arises, what is the power of sovereignty in today's society, at a time when international law is set at a ratio with internal sovereignty, sovereignty which in their absence would be absolute and undisputed. An analysis which begins with Maritain's concept of sovereignty as supreme power and as a natural and inalienable right, which takes absolute form. A treatment which appears as a ratio of the part with the whole, to the derivations on the political body, the people and the state and analyzes which of them has full sovereignty. For a deeper understanding, authority and power will also be analyzed as effects of sovereignty. The dynamics of this discussion includes other authors such as Fukuyama, with an analysis of the erosion of sovereignty or the compromise of sovereignty, as the principle on which the international order of modern power has been built. Seen in its optics as external interventions to strengthen legitimacy and neutralize weakness and lack of institutional capacity to implement internal policies.
\end{abstract}

Keywords: sovereignty, power, state, authority

\section{Authority and power}

According to Maritain (Maritain 2008: 167) "Authority and power are two different things: power is the force by which one compels others to obey". Authority is the right to direct and command others, the right for others to listen or obey. Authority demands power. Power without authority is tyranny. Clearly we come to a distinction, as mentioned in this statement, that power and authority should not be confused, firstly because authority means a right, which in the state of society comes as a result of an orderly and governing function of then if we stick to the logic of being governed, "... there must be people who command and people who obey .." ( Maritain 2008: 168 )

But if we speak of such order, perhaps submission, maybe the choice of the free will of the people, what conditions must we meet in order not to feel the arbitrary power of some against some? Governing on the basis of an order or law is enough, you just have to decide according to which law you will rule. If this absolutism brings sovereignty to the table, then we say that "authority derives from the will or consensus of the people and from their fundamental right to govern themselves ..." (Maritain 2008: 169) (ie freedom and the right to govern). ). If then we stick to the modern theory of sovereignty, which allows us to have a senate or in other words the delegation of power from below to a group of other individuals, naturally for Maritain such a delegation could not exist, for the essential reasons that were said above. 
According to Maritain "the whole theory of power in a democratic society is based precisely on the basis of the notion of representation or substitution through which the right of the people to govern themselves is exercised ..." (Maritain 2008: 171) Maritain also states that ".. the prince being the vicegerent of the people, is the parable of the people "(Maritain 2008: 172) I am fully convinced that if Machiavelli were to hear such a custom he could not disagree, either in part or in whole. As we analyze the claim that democracy places on political authority, we will have to return to another form of "authority" that Clastre (2014) would not like to call such. As I expressed in the first chapter, the presidency has a special value in this next chapter, which belongs entirely to its sovereignty and exercise in relation to the configurations, which I try to analyze to this point. Why such a choice regarding leadership as an institution? Firstly because in my approach to this topic I would like to leave aside any kind of centralization of power, insofar as I am talking about sovereignty and power, as well as society and the state, and secondly because leadership in my judgment is the historical dough of power. If we refer to Clastre (2014), we would have a problem in terminology, and we would not be accurate and right. Clastre reveals the idea that "... the leader lacks the main quality that makes him a true leader, namely the ability to exercise power over the community he leads" (Clastre 2014: 189). For him this impossibility does not mean that the leader has no role in this community, on the contrary he is there for a reason. Essentially his role comes as "... the right, or rather the duty of the spokesperson." (Clastre 2014: 190). In other words, "the primitive leader is first and foremost the one who undertakes to speak on behalf of society as a whole in cases where certain circumstances and events push him to enter into relationships with other communities." (Clastre 2014: 189). Therefore this leader is only the absolute embodiment of the will of the tribal society and the need to identify with the one, as a homogeneous whole. As for the way of "governing" this leader can not make decisions on his own. Every decision must definitely coincide with the desire of the tribe and nothing happens without getting approval in the majority. Let's say that for a decision, he wants to go to war with another clan, but in this decision the group does not agree, then the leader has no imposing power, because for Clastre he "is naked from of power." (Clastre 2014: 189).

According to Clastre, if this leader is elected, it is for the simple reason that he gains a minimum of trust, "based on the skills he needs to demonstrate precisely in the service of society as a whole." (Clastre 2014: 191). It is he who is commonly called the prestige of the leader and who, no less commonly, is abusively confused, of course, with power.

\section{On the state and sovereignty}

In his work, Man and the State, the French scholar Jaques Maritain devotes a special chapter to the importance of understanding sovereignty and its configurations, as far as the maintenance and conditioning of theory is concerned. According to Maritain (Maritain 2008: 65) "Sovereignty means two things: First, the right to supreme independence and supreme power which is a natural and inalienable right. Second, the right to independence and power which in their respective spheres are absolute or transcendental, not comparative or as the highest part of a whole. This first theory about the sovereign comes to us in the political and metaphysical form in the absolute sense, because as a concept it stands above the whole of power in question. He explains after this concept that sovereignty "does not accept escalation" (Maritain 2008: 66), insofar as it is an absolute attribute as we said above and inseparable. The next question that Maritan analyzes is: Who deserves "sovereignty"? The 
Maritain follows a three-derivative approach: over the political body, over the people, and over the state in its approach to who has full sovereignty. "The political body enjoys the right to full autonomy of ... internal ... to full external autonomy." (Maritain 2008: 68) “"

Maritain tells us that by "governing himself with a relatively high degree of independence ... that he also governs himself with a relatively high degree of power", brought about in today's society does not show the same strength as when international law was not known and when internal sovereignty was unquestioned. If these political bodies were part of an even larger political body they would not have the same skills in governance. In this interesting aspect of self-government we would understand the impossibility of a part of the political body to replace the whole with itself. This is in terms of the first essential element of sovereignty. Regarding the second element, that of absolutism, the political body is unknown because it is clear to Maritan that this political body does not govern itself separately from itself and from above itself.

On the other hand the author also treats the people, if he has the power for full sovereignty, right? "As far as the people are concerned, the second immanent element in true sovereignty its absolute character ... is not present in the people more than it is in the political body." (Maritain 2008: 72) Concerning the first character of sovereignty the people certainly have a natural right to independence and power, which consists of the people themselves for the people as a whole in relation to the various parts making "this all come in existence and in activity ". (Maritain 2008: 73) Undoubtedly the people, as well as the political body do not enjoy the right to sovereign absolutism because again, and here we must repeat, it does not govern itself "separately from itself and above itself." (Maritain 2008: 73)

As the analysis goes on and therefore we must progress in time, in spaces where sovereignty is taking another form, as seen above, not so absolute and transcendental as Maritan treated, to name an already contemporary author, like Fukuyama (2008) who has lived since the twentieth century, on what he says about the Erosion of Sovereignty. This subchapter of the work "State Building" helps us to understand what problems modern sovereignty faces. What do we mean by erosion of sovereignty? When we are poorly governed, sovereignty and the principle on which the international order of modern power is built will definitely be compromised. Fukuyama reminds us of the Westphelian international system, which dealt with a series of peace treaties in the 16th century, that ended the religious war at the time with a balance of 8 million victims, to pave the way for an international order of sovereign interstate. Already after the Westphelian system, sovereign states could co-exist thanks to this international law that was supposed to preserve the world order of peace.

Going back to the phenomenon of erosion, a weak state when problems start in governance, then opens troubles for itself and others around by "significantly increasing the possibility of someone else in the international system interfering in their internal affairs, contrary with their desires, to solve the problem through force. "(Fokuyama 2008: 144) Being weak in the lack of institutional capacity to implement policies, then there will be an intervention in strengthening the external legitimacy of the entire political system.

The experience of Somalia, or closer to us of the Balkans with humanitarian interventions, in troops and food aid "has produced abundant literature", (Fokuyama 2008: 145) says Fukuyama. "During the debates on humanitarian intervention, the issue was raised that the Westphelian system was no longer the right framework for international relations. It was 
argued that the end of the Cold War brought more consensus than before within the political and human rights community. "Sovereignty and hence legitimacy could no longer automatically be given to the de facto power that owned the country." (Fokuyama 2008: 145) For the author sovereignty was only a fabrication, in countries such as Somalia or Afghanistan, which had fallen under the subjugation of the great powers.

The humanitarian interventions of the 1990s led to the expansion of de facto international imperial power over the part of the world where the "failed states" belonged. Already the international community in these countries, like the ones mentioned above and others, "ceased to be an abstract presence and took on a tangible picture of the effective government of the countries in question" (Fokuyama 2008: 145). Fukuyama also leads the way in the Iraq War, launched by the Bush administration of the United States of America, after the horrific terrorist incident of September 2011, over the Twin Towers, where over 2996 innocent people lost their lives.

Since then, the Bush administration has pursued a series of tough domestic security and retaliatory offensive policies. However, Fukuyama reminds us that we need to be careful as such an issue cannot be considered on the basis of foreign and domestic policy factors alone, or at least as far as we see from the outside, beyond the roundtables. Paraphrasing the author, we can say that the Bush administration did not explore the real possibilities of the threat coming from Iraq to curb the threat, but combined "the threat coming from Iraq with the threat coming from terrorists in ways that did not accurately reflect the interests of differencies on both sides ". (Fokuyama 2008: 147)

So the principle of sovereignty per se will never be enough to protect a country that harbors such a threat. What is the solution according to Fukuyama? "Then solving this problem will lead to exactly the same result as humanitarian interventions: the need to go to such countries and take control of them, in order to eliminate these threats and prevent them from happening." happen in the future "(Fokuyama2008: 148)

\section{Fukuyama on the current state}

Fukuyama, comes to the conclusion of the observation and analysis of the state, as an author much discussed by academic scholars, extensively for his work "State Building". In his brief historical summary, Fukuyama points out that the state as we know it in the West is a late concept. At the beginning of the twentieth century, the state as he describes it was not widespread. There were no income taxes, no policies for the sick, the poor, the elderly or the unemployed, and almost no food safety regulations. States consumed about 10\% of GDP (Gross Domestic Product). By the 1980s they were taking up to 50\% of GDP, and in Sweden up to $70 \%$. (Fokuyama 2008: 65)

The rapid expansion of the inclusive state was in the 1930s with totalitarianism in the most left-leaning and right-wing states, the USSR and Nazi Germany, using highly efficient mechanisms of documenting and controlling the details of all citizens. Almost all totalitarian states had disappeared by 1989, and the prevailing orthodoxy that pervaded the Thatcherists and Reaganists was already the virtue of small governments. The advice, then, offered to underdeveloped countries that followed the 'Washington consensus' on neoliberalism was: reduce state intervention and increase economic profitability. In fact, as Fukuyama argues, these Third World countries should have been told to reduce the focus of the state in some 
areas and increase it in others. Neoliberal economic reforms had failed to be embraced mostly in these states and did them more harm in some aspects. Privatization in Russia, Fukuyama points out, often led to resource theft. Predatory regimes and groups flourished in SubSaharan Africa when state resources shifted into the hands of individuals, tribes, groups, and ethnic regions. In many states there was no effective state power to ensure that state resources would not be transferred to the privileged and predators, and there was no power to ensure that these resources continued to be used efficiently.

According Fokuyama (Fokuyama 2008: 123) until the early 1990s many economists preferred a limited space and a limited capacity over what they saw or considered as excessive scope and strong capacity. But by the early 1990s a new consensus developed, a conventionally wise replacement on the importance of 'governance', state capacity, institutional quality and institutional strengthening. Fukuyama quotes Milton Friedman, the 'dean of orthodox free markets', as saying that once his advice to countries transitioning from socialism was 'Privatization, privatization, privatization', but in 2001 he admitted that he was wrong. he thought that 'the rule of law' was 'more fundamental than privatization' ".(Fokuyama 2008: 69)

As Fukuyama warns, the fact that it now has a new conventional wisdom does not mean that it is entirely right. Given the performance of the past, the prevailing consensus must always be handled with caution. State building is the creation of new governing institutions and the strengthening of existing ones. "In this book, I argue that state-building is one of the most important issues for the world community because weak or failed states are the source of many of the world's most serious problems, from poverty to AIDS to drugs and terrorism." (Fokuyama 2008; 17) We observe from the very beginning that the macro approach to the magnifying glass of world political philosophy is a must, that is, a necessity. These new configurations of states and their power to influence other states, or especially "how to transfer strong institutions to developing countries", will be the main focus of political philosophy. Since "the century began with a liberal world order, led by the world's most liberal state, the United Kingdom", (Fokuyama 2008) then we need to understand that politics has become a game of real and economic mechanisms, as Faucault put it, a game of chess in which countries like, Great Britain or the United States of America, make the first move.

\section{Conclusion}

Sovereignty has been treated in its essential and peripheral aspect, capturing the evidence of various authors, to say the manner of using sovereignty as a constitutional order, as absolute power and as distributed power. In this paper we came to the conclusion that when we are poorly governed, the sovereignty and the principle on which the international order of modern power is built will definitely be compromised. According to Fokuyama, statebuilding is the creation of new governing institutions and the strengthening of existing ones, and a weak state when problems in governance start, then opens troubles for oneself and others around, significantly increasing the possibility of someone else in the international system interfering in their internal affairs.

Throughout the topics considered as the main symptoms, in the approach to the state, society and sovereignty that possess the circles of power, I can say that I have tried to make others understand that, the society already qualified as globalistic and universal, with the conditions of a technology of real mechanisms and evidenced in fact, under the framework of regional 
and also universal policies have the opportunity to know the history of their present. At its conclusion, the purpose of this paper, is declared as the need to return to the signs of the times by internalizing their messages and meaning, in terms of society and the way it seeks to live, under governance and rules of living.

\section{Bibliografy}

Francis Fukuyama. 2008. "State building, governance and world order in the twenty-first century", Tirana Times, Tirana

Pierre Clastre. 2014. "Society against the state", Point without Surface, Tirana

Jaques Maritain.2008. "Man against the state", DITA 2000, Tirana

Alan James, "The Practice of Sovereign Statehood in Contemporary International Society," "Political Studies," Volume 47 (3)

Malnes Midgaard, 2007. "Political Philosophy", Prishtina 